\title{
Serotyping of Bdellovibrios by Agglutination and Indirect Immunofluorescence
}

\author{
M. E. SCHELLING ${ }^{1 *}$ AND S. F. CONTI ${ }^{2}$ \\ Department of Biology, Texas A\&M University, College Station, Texas $77843^{1}$ and University of \\ Massachusetts, Amherst, Massachusetts $01002^{2}$
}

A comparative serological study was undertaken to clarify the uncertain interrelationships among various bdellovibrios. A total of 17 predacious (hostdependent) strains and 12 nonpredacious strains were serotyped. Strains were grouped into serotypes on the basis of positive agglutination and strongly positive fluorescence cross-reactions. The results of division of the strains into serogroups by these two methods were identical. Bdellovibrio starrii strain A3.12 and Bdellovibrio stolpii strain $\mathrm{UKi}_{2}$ were found to be antigenically distinct from each other and from the group of strains comprising Bdellovibrio bacteriovorus; the latter was found to be an antigenically heterogeneous group consisting of at least nine serogroups. All nonpredacious strains were found to be related antigenically to their obligately predacious counterparts. An antigen(s) common to all of the Bdellovibrio strains examined was exhibited as weakly positive fluorescence. Selected strains of Bdellovibrio were studied by Ouchterlony immunodiffusion, which confirmed the serogrouping results and provided a technically simple method of serotyping. Further immunochemical characterization of the strains of Bdellovibrio in conjunction with increased knowledge of other differences among strains will likely result in the formation of additional species of Bdellovibrio.

Research interest in Bdellovibrio is related to the many intriguing characteristics of this genus. Bdellovibrio strains are gram-negative, bacteriolytic organisms which prey $(10,14)$ on gramnegative bacteria $(3,5,21)$. The role of Bdellovibrio in the environment has not been well established, but its primary importance may lie in the ecological balance between pathogenic and nonpathogenic bacteria in soil, sewage, and water (22).

The taxonomic position of the genus Bdellovibrio and the interrelationships among the strains of this genus have remained uncertain. The use of predation as a primary criterion to allow an unknown strain to be recognized as Bdellovibrio has resulted in a heterogeneous assemblage of organisms. Determination of strains of Bdellovibrio on the basis of prey range and location of isolation has been unsatisfactory, and at present other differences among strains are used in determining the interrelationships among strains. Known differences among selected strains of Bdellovibrio include differences in guanine-plus-cytosine content $(15,16$, 18), deoxyribonucleic acid ribosomal binding sites, enzyme migration patterns (16), levels of protease activity (8), and susceptibility to phage lysis (1). Our knowledge of the nutritional and metabolic characteristics of strains of Bdellovibrio is incomplete and, therefore, not useful taxonomically.
As serotyping of bacterial strains has been widely accepted as useful in determining relationships among groups of bacteria, and few studies (22-24) have reported data showing relationships among bdellovibrios, an immunological study of the interrelationships among various strains of Bdellovibrio was undertaken to provide additional information which may be useful in the formation of a more unified concept of the genus Bdellovibrio.

\section{MATERIALS AND METHODS}

Culture of nonpredacious strains of Bdellovibrio. The medium used for culture of nonpredacious strains of Bdellovibrio was peptone-yeast extract broth, which contained $1 \%$ peptone and $0.3 \%$ yeast extract (Difco Laboratories) and was adjusted to $\mathrm{pH} 7.2$. Cultures were transferred by using $10 \%$ (vol/vol) inocula and were grown for $16 \mathrm{~h}$ at $30^{\circ} \mathrm{C}$ in a Psychrotherm shaking incubator (New Brunswick Scientific Co.).

Culture of predacious strains of Bdellovibrio. Escherichia coli ATCC 15144 was used as prey to propagate all of the predacious Bdellovibrio strains examined except strains 6-5-S and 118. Strain 6-5-S was grown on Spirillum serpens ATCC 12638, and strain 118 was grown on Serratia marcescens ATCC 13880.

The prey cells were grown in nutrient broth (Difco) at $30^{\circ} \mathrm{C}$ for $10 \mathrm{~h}$ in a shaking incubator, centrifuged, washed, and suspended in dilute nutrient broth $0.008 \%$ nutrient broth, $0.005 \%$ Casamino Acids, $0.001 \%$ yeast extract [Difco]) supplemented with 2 $\mathrm{mM} \mathrm{CaCl}_{2}$ and $3 \mathrm{mM} \mathrm{MgCl}_{2}$. Lysates were transferred to prey cell cultures by using $10 \%(\mathrm{vol} / \mathrm{vol})$ inocula and 
these cultures were grown for 12 to $48 \mathrm{~h}$ at $30^{\circ} \mathrm{C}$ in a Psychrotherm shaking incubator.

Preparation of anti-Bdellovibrio antisera. Nonpredacious Bdellovibrio antigens were prepared by adding equal volumes of $1 \%$ Formalin ( $40 \%$ formaldehyde) in $0.85 \%(\mathrm{wt} / \mathrm{vol}) \mathrm{NaCl}$ to 16 -h cultures grown as described above.

Antigens of predacious Bdellovibrio strains were prepared from lysates which were filtered through $0.45-\mu \mathrm{m}$ membrane filters (Millipore Corp.) to separate the bdellovibrios from any remaining prey cells. The filtrates were sedimented at $7,710 \times g$ in a Sorvall model RC-2 preparative centrifuge and suspended in $0.5 \%$ Formalin in $0.85 \%$ (wt/vol) $\mathrm{NaCl}$. Facultative strain $\mathrm{UKi}_{2}$ was grown saprophytically in peptoneyeast extract broth and transferred three times at $12-\mathrm{h}$ intervals. A $10 \%$ (vol/vol) inoculum was taken from the third transfer and grown on prey cells in the same manner as other predacious strains. After three cycles of predacious growth, an antigen preparation was made as described above. Antigen preparations were standardized spectrophotometrically.

The antisera used for the agglutination and indirect immunofluorescence procedures were raised in New Zealand white rabbits which were given six intravenous injections increasing from 0.2 to $4.0 \mathrm{ml}$ of antigen during an 8-week period.

Antisera with titers high enough to be used in precipitation tests were obtained by weekly intramuscular injection of $2 \mathrm{ml}$ of antigen which had been emulsified with an equal volume of Freund incomplete adjuvant (Difco) for 8 months to 1 year.

The sera were obtained by centrifuging coagulated whole blood at $7,000 \times g$ for $15 \mathrm{~min}$ in an International Equipment Co. refrigerated centrifuge and were stored at $-20^{\circ} \mathrm{C}$ until they were used.

FITC-labeled antisera. The fluorescein isothiocyanate (FITC)-labeled caprine anti-rabbit immunoglobulin $\mathrm{G}$ (IgG) antibody with specificity for both heavy and light immunoglobulin chains and the FITC-labeled caprine anti-rabbit $\operatorname{IgM}$ antibody with specificity for the $\mu$ chain (Microbiological Associates) contained 10 $\mathrm{mg}$ of protein per $\mathrm{ml}$ and 1:10,000 parts of thimerosal preservative.

Preparation of antigens for use in indirect immunofluorescence and agglutination. Antigens for use in the indirect immunofluorescence procedure were prepared from cultures grown as described above.

Cultures of nonpredacious organisms up to $24 \mathrm{~h}$ old were used in this study. Bdellovibrio broth cultures were centrifuged at $4,000 \times g$ for $20 \mathrm{~min}$ in a Sorvall model RC-2 preparative centrifuge. The cells were suspended in $1 \%$ Formalin (40\% formaldehyde) in $0.85 \%(\mathrm{wt} / \mathrm{vol}) \mathrm{NaCl}$ and stored at $4^{\circ} \mathrm{C}$.

The predacious Bdellovibrio cultures used were up to $48 \mathrm{~h}$ old. These cultures were filtered through 0.45 $\mu \mathrm{m}$ Millipore filters to separate the bdellovibrios from their prey and then were washed three times by centrifuging them at $4,000 \times g$ for $20 \mathrm{~min}$ and suspending the pellet in $0.85 \%$ ( $\mathrm{wt} / \mathrm{vol}$ ) $\mathrm{NaCl}$. At the end of the final wash, the bdellovibrios were suspended in $1 \%$ Formalin ( $40 \%$ formaldehyde) in $0.85 \%$ (wt/vol) $\mathrm{NaCl}$

Fresh broth cultures and Formalin-treated stock cultures could be used interchangeably as antigens in the indirect immunofluorescence procedure.

The antigens used in tube agglutination tests were prepared as described above and were adjusted with
$0.85 \%(\mathrm{wt} / \mathrm{vol}) \mathrm{NaCl}$ to densities of approximately $3 \times$ $10^{9}$ bacteria per $\mathrm{ml}$.

Agglutination procedure. A 1:5 dilution of heatinactivated $\left(56^{\circ} \mathrm{C}, 30 \mathrm{~min}\right)$ antiserum was further diluted through a series of twofold dilutions to 163,840 . An equal volume of the antigen preparation being tested was added to each tube, which doubled the dilution of the antiserum.

A control series of tubes contained heat-inactivated normal rabbit sera starting at a dilution of 1:5 in $0.85 \%$ (wt/vol) $\mathrm{NaCl}$ and equal volumes of antigen suspension

All tubes were incubated at $37^{\circ} \mathrm{C}$ for $1 \mathrm{~h}$ and then refrigerated overnight at $4^{\circ} \mathrm{C}$.

Indirect immunofluorescence procedure. A smear was prepared from a broth culture or from a Formalintreated $B$ dellovibrio stock culture and mixed by gentle heat. The slide was placed in a petri dish containing a disk of moistened filter paper to prevent drying on the slide. The smear was covered with rabbit anti-Bdellovibrio antiserum and incubated at room temperature $\left(22^{\circ} \mathrm{C}\right)$ or at $30^{\circ} \mathrm{C}$ for $30 \mathrm{~min}$, washed gently three times by allowing pipettefuls of phosphate buffer $(6.4 \mathrm{~g}$ of $\mathrm{Na}_{2} \mathrm{HPO}_{4}, 1.3 \mathrm{~g}$ of $\mathrm{NaH}_{2} \mathrm{PO}_{4} \cdot \mathrm{H}_{2} \mathrm{O}, \mathrm{pH}$ 7.4) to run over the area of the smear, and incubated in a second moist chamber for $30 \mathrm{~min}$ at room temperature $\left(22^{\circ} \mathrm{C}\right)$ or at $30^{\circ} \mathrm{C}$ with smear covered with FITC-labeled caprine anti-rabbit IgG antibody (Microbiological Associates). The slide was again washed three times with phosphate buffer, air dried, covered with Difco fluorescent antibody mountant, and protected with a cover slip. Slides were observed immediately to avoid bleaching, which is particularly important when reading both weak and strong fluorescence, such as in the $B$ dellovibrio system.

Five controls were run for each group of slides tested by the indirect immunofluorescence procedure. A negative control for nonspecific fluorescence resulting in false positives consisted of a primary incubation with the smear coated with known negative normal rabbit serum, followed by a second incubation with FITC-labeled anti-rabbit IgG. This control detected nonspecific binding of FITC-labeled anti-rabbit IgG or inadequate washing. A negative control for the detection of any inherent Bdellovibrio fluorescence which was not specific for the system consisted of a primary incubation only. A pre-injection serum control for the rabbit from which the experimental serum was taken was used to determine that no innate antibodies which could cross-react with Bdellovibrio antigens were present. A known strongly positive fluorescence system and a known weakly positive fluorescence system were run as standards for reading of the fluorescent antibody technique. Additionally, prey cells were tested with predacious and nonpredacious antisera. No fluorescence was observed.

The use of caprine FITC-labeled anti-rabbit IgM immunoglobulin with specificity for the $\mu$ chain (Microbiological Associates) in addition to the caprine FITC-labeled anti-rabbit IgG provided no increase in resolution.

Fluorescence microscopy. A Zeiss Standard Universal microscope with attachments for fluorescence microscopy, including a model HBO $200 \mathrm{~W} / 4$ superpressure mercury lamp, was used for reading the prepared slides. A $\times 100$ planapochromatic oil immersion objective with an iris was used. The filter combi- 
TABLE 1. Antigenic differentiation of nonpredacious Bdellovibrio strains by indirect immunofluorescence and agglutination ${ }^{a}$

\begin{tabular}{|c|c|c|c|c|c|c|c|c|c|c|c|c|c|c|c|c|c|}
\hline \multirow[b]{2}{*}{ Antiserum } & \multicolumn{17}{|c|}{ Antigen } \\
\hline & $\mathrm{UKi}_{\mathrm{J}}$ & $\mathrm{UKi}_{2}$ & $\mathrm{SaD}_{3} \mathrm{Sm}^{\mathrm{r}-}$ & A3.12 & 118 & 120 & 11 & & $E$ & $\begin{array}{c}2484- \\
\mathrm{Se}_{2}\end{array}$ & $\begin{array}{c}2484- \\
\mathrm{Se}_{3}\end{array}$ & 100 & D & Xty & $\begin{array}{l}\text { Sa- } \\
109\end{array}$ & 109 & OX9-3 \\
\hline $\mathrm{UKi}_{1}$ & $+{ }^{b}$ & & & & & & & & & & & & & & & & \\
\hline $\mathrm{UKi}_{2}$ & & + & & & & & & & & & & & & & & & \\
\hline $\mathrm{SaD}_{3} \mathrm{Sm}^{\mathrm{r}-}$ & & & + & & & & & & & & & & & & & & \\
\hline $\mathrm{A} 3.12$ & & & & + & & & & & & & & & & & & & \\
\hline 118 & & & & & + & + & \pm & & & & & & & & & & \\
\hline 120 & & & & & + & + & + & & & & & & & & & & \\
\hline 110 & & & & & + & + & \pm & & & & & & & & & & \\
\hline B & & & & & & & & & $t$ & & & & & & & & \\
\hline $\mathrm{E}$ & & & & & & & & & + & & & & & & & & \\
\hline $2484-\mathrm{Se}_{2}$ & & & & & & & & & & + & + & & & & & & \\
\hline $2484-\mathrm{Se}_{3}$ & & & & & & & & & & + & + & & & & & & \\
\hline 100 & & & & & & & & & & & & + & + & + & + & + & + \\
\hline D & & & & & & & & & & & & + & + & + & + & + & + \\
\hline Xty & & & & & & & & & & & & + & + & + & + & + & + \\
\hline Sa-109 & & & & & & & & & & & & + & + & + & + & + & + \\
\hline 109 & & & & & & & & & & & & + & + & + & + & + & + \\
\hline$\overline{O X 9-3}$ & & & & & & & & & & & & + & + & + & + & + & + \\
\hline
\end{tabular}

${ }^{a}$ Nonpredacious Bdellovibrio antigens and nonpredacious Bdellovibrio antisera were used.

$b+$, Agglutination and strongly positive fluorescence. Weakly positive fluorescence was observed on all slides that did not exhibit strongly positive fluorescence.

nation that gave optimum fluorescence consisted of BS 12 and BG 38 exciter filters in conjunction with a no. 50 barrier filter.

\section{RESULTS}

A total of 17 predacious and 12 nonpredacious strains of Bdellovibrio were serotyped. All nonpredacious, predacious, and facultative strains were tested with both homologous sera and all heterologous antisera for positive agglutination and fluorescence. In all test slides, fluorescence was either strongly positive or weakly positive.

Table 1 shows the data obtained when nonpredacious strains were assayed against nonpredacious antisera. Each antigen reacted with its homologous antiserum to produce agglutination and strongly positive fluorescence. Antigenically related strains, as determined by positive agglutination and strongly positive fluorescence, grouped the nonpredacious strains into eight serologically distinct groups. Weak fluorescence, presumably due to a common Bdellovibrio antigen, was present in all slides that did not exhibit strongly positive fluorescence.

Table 2 shows the data obtained when predacious strains were assayed against antisera formed in response to predacious strains. Each antigen reacted with its homologous antiserum to produce agglutination and strongly positive fluorescence. Antigenic relationships, as determined by positive agglutination and strongly positive immunofluorescence, divided the nonpredacious strains into seven serologically dis- tinct groups. Weak fluorescence, presumably due to a common Bdellovibrio antigen, was present in all slides that did not exhibit a strongly positive fluorescence.

The serological relationships between the nonpredacious and predacious strains are shown in Table 3. All predacious and nonpredacious variants of the same strain were found to be antigenically related, as evidenced by agglutination and strongly positive fluorescence crossreactions (e.g., strains $\mathrm{UKi}_{2}, \mathrm{~A} 3.12, \mathrm{E}, \mathrm{D}, \mathrm{Xty}$, and 109). We found that certain nonpredacious groups and certain predacious groups of strains are antigenically related; the large group of antigenically related nonpredacious strains is antigenically related to the large group of antigenically related predacious strains, and predacious strains $\mathrm{B}$ and $\mathrm{E}$ are related to predacious strain E. Weak fluorescence was present in all slides that lacked a strongly positive fluorescence.

Table 4 shows the consolidation of antigenically related strains of bdellovibrios to form serogroups. The members of each serogroup cross-reacted by agglutinating and exhibiting strongly positive fluorescence. There was no agglutination or strongly positive fluorescence cross-reactions between members of different serogroups.

The weak fluorescence observed in all Bdellovibrio slides that did not exhibit strongly positive fluorescence was not observed with any other bacterium tested. 
TABLE 2. Antigenic differentiation of predacious Bdellovibrio strains by indirect immunofluorescence and agglutination $^{a}$

\begin{tabular}{|c|c|c|c|c|c|c|c|c|c|c|c|c|c|c|c|}
\hline \multirow{2}{*}{$\begin{array}{l}\text { Anti- } \\
\text { serum }\end{array}$} & \multicolumn{15}{|c|}{ Antigen } \\
\hline & 6-5-S & $\mathrm{E}$ & 114 & Xty & 109D & $109 \mathrm{~J}$ & 109 & OX9-2 & $\mathrm{D}$ & 100 & A3.12 & w & $\mathrm{UKi}_{2}$ & 118 & 110 \\
\hline $6-5-S$ & $t^{b}$ & & & & & & & & & & & & & & \\
\hline$\overline{\mathrm{E}}$ & & + & & & & & & & & & & & & & \\
\hline 114 & & & + & & & & & & & & & & & & \\
\hline $\mathrm{D}$ & & & & + & + & + & + & + & + & + & & & & & \\
\hline$\overline{X t y}$ & & & & + & + & + & + & + & + & + & & & & & \\
\hline 109D & & & & + & + & + & + & + & + & + & & & & & \\
\hline$\overline{109 J}$ & & & & + & + & + & + & + & + & + & & & & & \\
\hline 109 & & & & + & + & + & + & + & + & + & & & & & \\
\hline OX9-2 & & & & + & + & + & + & + & + & + & & & & & \\
\hline A3.12 & & & & & & & & & & & + & & & & \\
\hline $\mathrm{W}$ & & & & & & & & & & & & + & & & \\
\hline $\mathrm{UKi}_{2}$ & & & & & & & & & & & & & + & & \\
\hline
\end{tabular}

${ }^{a}$ Predacious Bdellovibrio antigens and predacious Bdellovibrio antisera were used.

$b^{b}+$, Agglutination and strongly positive fuorescence. Weakly positive fluorescence was observed on all slides that did not exhibit strongly positive fluorescence.

The Fig. 1 immunodiffusion plate shows that the antigenic relationships of Bdellovibrio starrii strain A3.12 and Bdellovibrio stolpii strain $\mathrm{UKi}_{2}$ to Bdellovibrio bacteriovorus strain 100 . B. stolpii and $B$. starrii were found to be antigenically distinct from $B$. bacteriovorus, considering the limits of resolution of this technique. In similar plates in which nonpredacious strain $\mathrm{UKi}_{2}$ antigen or nonpredacious strain A3.12 antigen was used, only homologous systems precipitated.

Figure 2 shows that as determined by the Ouchterlony immunodiffusion technique, $B$.

TABLE 3. Antigenic relationships of nonpredacious Bdellovibrio strains to predacious Bdellovibrio strains as determined by indirect immunofluorescence and agglutination ${ }^{a}$

\begin{tabular}{|c|c|c|c|c|c|c|c|c|c|c|c|c|c|c|c|c|c|}
\hline \multirow{2}{*}{$\begin{array}{l}\text { Anti- } \\
\text { serum }\end{array}$} & \multicolumn{17}{|c|}{ Antigen } \\
\hline & $\mathrm{UKi}_{1}$ & $\mathrm{UKi}_{2}$ & $\mathrm{SaD}_{3} \mathrm{Sm}^{\mathrm{r}-}$ & A3.12 & 118 & 120 & 110 & B & $\mathbf{E}$ & $\begin{array}{c}2484- \\
\mathrm{Se}_{2}\end{array}$ & $\begin{array}{c}2484- \\
\mathrm{Se}_{3}\end{array}$ & 100 & D & Xty & $\begin{array}{l}\text { Sa- } \\
109\end{array}$ & 109 & OX9-3 \\
\hline $6-5-S$ & $-^{b}$ & & & & & & & & & & & & & & & & \\
\hline $\mathrm{E}$ & & & & & & & & + & + & & & & & & & & \\
\hline \multicolumn{18}{|l|}{114} \\
\hline $\mathrm{D}$ & & & & & & & & & & & & + & + & + & + & + & + \\
\hline Xty & & & & & & & & & & & & + & + & + & + & + & + \\
\hline 109D & & & & & & & & & & & & + & + & + & + & + & + \\
\hline $109 \mathrm{~J}$ & & & & & & & & & & & & + & + & + & + & + & + \\
\hline 109 & & & & & & & & & & & & + & + & + & + & + & + \\
\hline OX9-2 & & & & & & & & & & & & + & + & + & + & + & + \\
\hline A3.12 & & & & + & & & & & & & & & & & & & \\
\hline \multicolumn{18}{|l|}{ W } \\
\hline $\mathrm{UKi}_{2}$ & & + & & & & & & & & & & & & & & & \\
\hline
\end{tabular}

${ }^{a}$ Nonpredacious Bdellovibrio antigens and predacious Bdellovibrio antisera were used.

$b+$, Agglutination and strongly positive fluorescence. Weakly positive fluorescence was observed on all slides that did not exhibit strongly positive fluorescence. 
TABLE 4. Serogroups as established by agglutination and indirect immunofluorescence

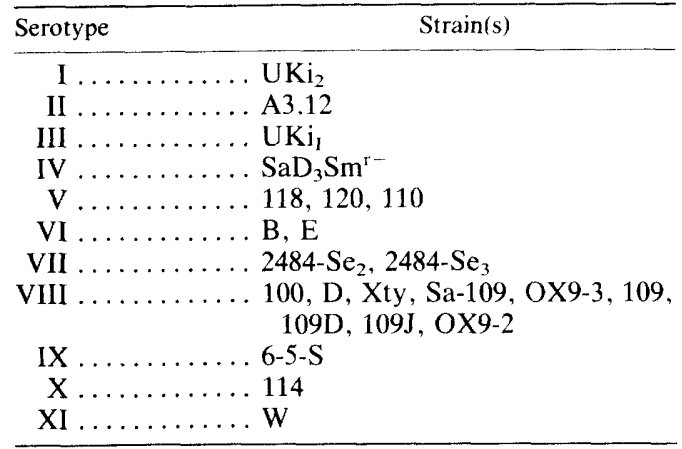

bacteriovorus holotype strain 100 was antigenically distinct from other members of the species $B$. bacteriovorus which are members of other serogroups.

Ouchterlony immunodiffusion data (Fig. 1 and 2) confirm the serotyping data from the agglutination and indirect immunofluorescence procedures and provide a technically simple method for serotyping.

Table 5 compares the division of strains by serotyping and the division of strains by phage typing. The phage typing data (1) are in general

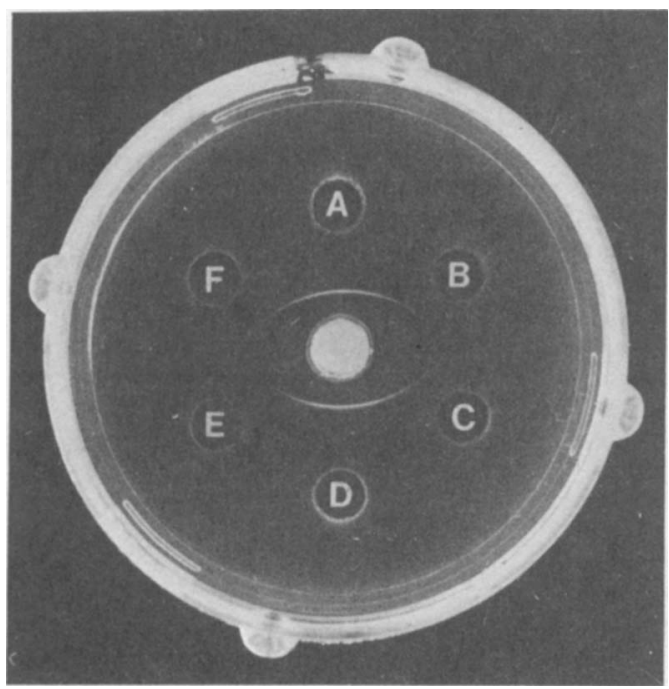

FIG. 1. Antigenic relationships of $B$. stolpii and $B$. starrii to $B$. bacteriovorus, as resolved by Ouchterlony immunodiffusion. Well A, anti-NP $100(B$. bacteriovorus); well B, anti-NP A3.12 (B. starrii); well C, antiNP $\mathrm{UKi}_{2}$ (B. stolpii); well D, anti-NP 100 ; well $\mathrm{E}$, normal rabbit serum; well $F$, anti-NP $\mathrm{UKi}_{2}$; center well, Formalin-treated NP 100 antigen. The results were identical with fresh or Formalin-treated, sonicated or unsonicated antigen.

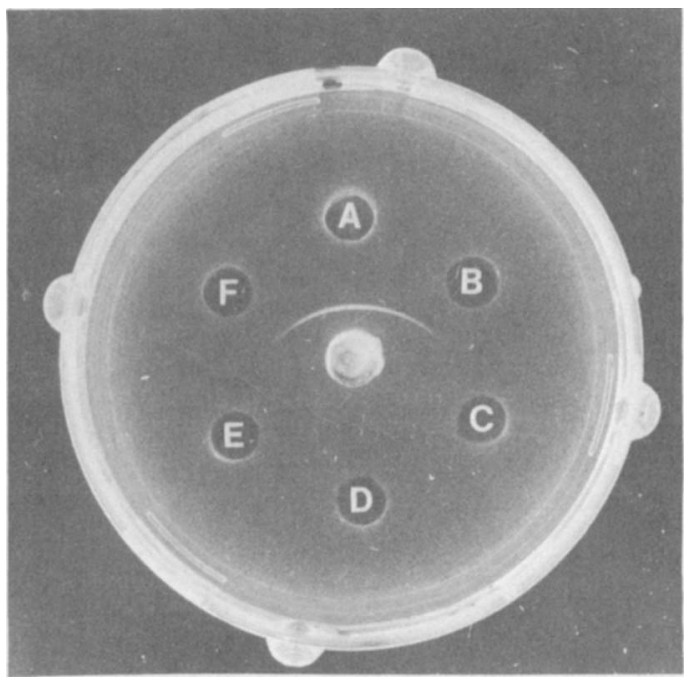

FIG. 2. Antigenic relationships of B. bacteriovorus strain 100 to strains of $B$. bacteriovorus which are members of other serogroups. Well A, anti-NP 100 (serogroup VIII, B. bacteriovorus); well B, anti-NP 118 (serogroup $\mathrm{V}, B$. bacteriovorus); well $\mathrm{C}$, anti-NP $\mathrm{SaD}_{3} \mathrm{Sm}^{\mathrm{r}-}$ (serogroup IV $B$. bacteriovorus); well D, normal rabbit serum (control; well $\mathrm{E}$, anti-NP UKi, (serogroup III, B. bacteriovorus); well F, anti-NP $2484-\mathrm{Se}_{2}$ (serogroup VII, B. bacteriovorus). The antigen was sonicated (four times, 5 s) nonpredacious strain 100 Formalin-treated antigen stock. The results were identical with fresh or Formalin-treated, sonicated or unsonicated antigen.

agreement with the data establishing serogroups. Phages HDC-1, HDC-2, and MAC-6 each lysed members of only one serogroup. MAC-1 and MAC-3 had broad specificities that included seven serogroups. The only discrepancies between the division of strains by phage typing and the division of strains by serotyping were that MAC-1 distinguished among members of serogroup $\mathrm{V}$ by lysing strain 118 and not lysing strains 110 and 120 and MAC-3 lysed some but not all members of serogroup VIII.

\section{DISCUSSION}

It is interesting to consider the serotyping data in relation to the current classification of the bdellovibrios as presented in Bergey's Manual of Determinative Bacteriology, 8th ed. (5). Our data support the current classification in that $B$. stolpii, $B$. starrii, and $B$. bacteriovorus were found to be antigenically distinct. $B$. stolpii (serotype I) showed no strong antigenic similarity to any of the other strains of Bdellovibrio. $B$. starrii (serotype II) also showed no strong antigenic similarity to any of the other strains of $B$ dellovibrio. The heterogeneity of the assemblage of strains currently designated $B$. bacterio- 
TABLE 5. Comparison of the division of strains by serotyping and the division of strains by phage typing ${ }^{a}$

\begin{tabular}{ccc} 
Phage & $\begin{array}{c}\text { Serogroup(s) } \\
\text { lysed }\end{array}$ & $\begin{array}{c}\text { Points at which division of } \\
\text { strains by phage typing } \\
\text { differs from division of } \\
\text { strains by serotyping }\end{array}$ \\
\hline
\end{tabular}

HDC-1 I

HDC-2 I

MAC-1 I, IV, V, V1, VII, VIII, X

MAC-1 lyses strain 118 but not strains 110 and 120 of serogroup $\mathrm{V}$

MAC-3 I, IV, V, VI, VII, VIII, $X$

MAC-3 lyses strains 100 and 109 but not strains D, OX9-2, OX9-3, Xty, and Sa-109 of serogroup VIII

\section{MAC-6 VI}

${ }^{a}$ Strains $\mathrm{UKi}_{2}$ (serogroup III) and $\mathrm{A} 3.12$ (serogroup II) were not lysed by any of the phage. See reference 1.

vorus is evidenced by the antigenic differences found among the strains studied, which allowed the formation of nine serogroups within this species. There are additional differences among the strains designated $B$. bacteriovorus; for example, strain W produces bdellocysts (2), strain 6-5-S preys upon Spirillum serpens and is facultatively predacious (13), and there are marine isolates that have deoxyribonucleic acid guanine-plus-cytosine contents which differ from those of the described terrestrial species and high sodium chloride requirements (23). Along with antigenic differences and further immunochemical characterization, such differences may warrant the designation of new species, although at this point the naming of new species seems premature.

The antigenic characteristics of the bdellovibrios as revealed by serological techniques may eventually allow positive identification of questionable strains as members of the genus Bdellovibrio, as the antigen or antigens detected as weakly positive immunofluorescence are common to all strains of Bdellovibrio studied thus far and to no other bacteria so far examined. The existence of a Bdellovibrio common antigen has been suggested by Kramer and Westergaard (12).

\section{LITERATURE CITED}

1. Althauser, M., W. Samsonoff, C. Anderson, and S. F. Conti. 1972. Isolation and preliminary characterization of bacteriophages for Bdellovibrio bacteriovorus. J. Virol. 10:516-523.

2. Burger, A., G. Drews, and R. Ladwig. 1968. Wirtskreis und Infektions-cyclus eines neu isolirten Bdellovibrio bac- teriovorus-stammes. Arch. Mikrobiol. 61:261-279.

3. Burnham, J. C., T. Hashimoto, and S. F. Conti. 1968. Electron microscopic observations on the penetration of Bdellovibrio bacteriovorus into gram-negative bacterial hosts. J. Bacteriol. 96:1366-1381.

4. Burnham, J. C., T. Hashimoto, and S. F. Conti. 1970. Ultrastructure and cell division of a facultatively parasitic strain of Bdellovibrios bacteriovorus. J. Bacteriol. 101:997-1004.

5. Burnham, J. C., and J. Robinson. 1974. Genus Bdellovibrio Stolp and Starr 1963, 243, p. 212-214, In R. E Buchanan and N. E. Gibbons (ed.), Bergey's manual of determinative bacteriology, 8th ed. The Williams \& Wilkins Co., Baltimore.

6. Deidrich, D. L., C. F. Denny, T. Hashimoto, and S. F. Conti. 1970. Facultatively parasitic strain of Bdellovibrio bacteriovorus. J. Bacteriol. 101:989-996.

7. Fabio, U., and G. Zanasi Aggazzotti. 1970. Caratteristiche antigeniche di nutanti saprofiti di batteriovori. G. Batteriol. Virol. Immunol. Ann. Osp. Maria Vittoria Torino 63:784-803

8. Gloor, L., B. Klubek, and R. J. Seidler. 1974. Molecular heterogeneity of bdellovibrios: metallo and serine proteases unique to each species. Arch. Microbiol. 95:45-56.

9. Hashimoto, T., D. L. Diedrich, and S. F. Conti. 1970 Isolation of bacteriophage for Bdellovibrio bacteriovorus. J. Virol. 5:97-98.

10. Hespell, R. B., R. A. Rosson, M. F. Thomashow, and S. C. Rittenberg. 1973. Respiration of Bdellovibrio bacteriovorus strain $109 \mathrm{~J}$ and its energy substrates for intraperiplasmic growth. J. Bacteriol. 113:1280-1288.

11. Hoeniger, J. F. M., R. Ladwig, and H. Moor. 1972. The fine structure of "resting bodies" of Bdellovibrio sp. strain W developed in Rhodospirillum rubrum. Can. J. Microbiol. 18:87-92.

12. Kramer, T. T., and J. M. Westergaard. 1977. Antigenicity of bdellovibrios. Appl. Environ. Microbiol. 33:967-970.

13. Reiner, A. M., and M. Shilo. 1969. Host-independent growth of Bdellovibrio bacteriovorus in microbial extracts. J. Gen. Microbiol. 59:401-410.

14. Ross, E. J., C. F. Robinow, and J. Robinson. 1974. Intracellular growth of Bdellovibrio bacteriovorus 6-5-S in heat-killed Spirillum serpens VHL. Can. J. Microbiol. 20:847-851.

15. Scherff, R. H., J. E. DeVay, and T. W. Carroll. 1966. Ultrastructure of host parasitic relationships involving reproduction of Bdellovibrio bacteriovorus in host bacteria. Phytopathology 56:627-632.

16. Seidler, R. J., M. Mandel, and J. N. Baptist. 1972. Molecular heterogeneity of the bdellovibrios: evidence of two new species. J. Bacteriol. 109:209-217.

17. Seidler, R. J., and M. P. Starr. 1969. Isolation and characterization of host-independent bdellovibrios. J. Bacteriol. 100:769-785.

18. Seidler, R. J., M. Starr, and M. Mandel. 1969. Deoxyribonucleic acid characterization of bdellovibrio. J. Bacteriol. 100: $786-790$

19. Shilo, M. 1966. Predatory bacteria. Sci. J. 2:33-77.

20. Shilo, M., and B. Bruff. 1965. Lysis of gram-negative bacteria by host-independent ectoparasitic Bdellovibrio bacteriovorus isolates. J. Gen. Microbiol. 40:317-328.

21. Starr, M. P., and N. L. Baigent. 1966. Parasitic interaction of Bdellovibrio bacteriovorus with other bacteria. J. Bacteriol. 91:2005-2017.

22. Stolp, H. 1973. The bdellovibrios: bacterial parasites of bacteria. Annu. Rev. Phytopathol. 11:492-517.

23. Taylor, V. I., P. Baumann, J. L. Reichelt, and R. D. Allen. 1974. Isolation, enumeration, and host range of marine bdellovibrios. Arch. Microbiol. 98:101-114.

24. Varon, M., and R. Levisohn. 1972. Three-membered parasitic system: a bacteriophage, Bdellovibrio bacteriovorus, and Escherichia coli. J. Virol. 9:519-525. 